\title{
MANAJEMEN WAKTU BELAJAR DARING MAHASISWA SELAMA PANDEMI COVID-19 \\ ${ }^{1}$ Queen Elvina Sevtivia Asrivi
}

${ }^{1}$ Pendidikan Guru Madrasah Ibdtidaiyah (PGMI)

Institut Agama Islam Bakti Negara (IBN) Tegal

\begin{abstract}
ABSTRAK
Tujuan penelitian ini adalah mendeskripsikan manajemen waktu belajar mahasiswa PGMI Semester IV selama Pandemi Covid-19 melalui model hybrid learning mata kuliah Pembelajaran Tematik Terpadu. Adaptasi Kebiasaan Baru (AKB) salah satu langkah manusia supaya produktif beaktifitas selama pandemi Covid-19. Sektor pendidikan tinggi melalui SE Mendikbud No. 0173/E.E2/PM/2021 mengenai pelaksanaan perkuliahan menggunakan model hybrid learning dengan pelaksanaan secara daring dan luring secara bergantian. Hal tersebut didasari kebijakan perkuliahan sifting dari Institut Agama Islam Bakti Negara (IBN) Tegal. Metode penelitian ini kualitatif deskriptif menggunakan analisis data Miles and Huberman dengan tahapan pengumpulan, reduksi data, analisis dan interpretasi data. Keabsahan data menggunakan triangulasi teknik dan sumber. Teknik yaitu wawancara, kuesioner dan observasi sedangkan sumber berupa partisipan penelitian yang bekerja baik dalam atau luar sektor pendidikan. Subjek penelitian yaitu mahasiswa PGMI Angkatan 2019 sebanyak 5 mahasiswa. Hasil penelitian ini mahasiswa memiliki manajemen waktu belajar yang baik ditandai dengan komitmen bekerja dan kuliah, pembagian waktu bekerja dan kuliah terjadwal dengan baik selama AKB didukung dengan platform edukasi Google Clasroom dan media YouTube. Mahasiswa yang bekerja baik sektor pendidikan maupun diluar itu memiliki motivasi memiliki kompetensi tinggi dan siap menghadapi kompetisi masa depan.
\end{abstract}

Kata kunci: Adaptasi Kebiasaan Baru (AKB), Hybrid Learning, Manajemen Waktu Belajar

\begin{abstract}
The purpose of this study is to describe the learning time management of PGMI Semester IV students during the Covid-19 pandemic through a hybrid learning model for Integrated Thematic Learning courses. New normal is one of human steps to be productive in activities during the Covid-19 pandemic. The higher education sector through the Minister of Education and Culture Decree Number 0173/E.E2/PM/2021 regarding the implementation of lectures using a hybrid learning model with alternate online and offline implementation. This is based on the shifting lecture policy from Institut Agama Islam Bakti Negara (IBN) Tegal. This descriptive qualitative research method uses Miles and Huberman data analysis with the stages of data collection, data reduction, analysis and interpretation of data. The validity of the data using triangulation techniques and sources. The techniques are interviews, questionnaires and observations, while the sources are research participants who work either inside or outside the education sector. The research subjects were 5 students of PGMI Class of 2019 as many as 5 students. The results of this study indicate that students have good study time management as indicated by a commitment to work and study, the division of work time and
\end{abstract}


well-scheduled lectures as long as new normal is supported by the Google Classroom educational platform and YouTube media. Students who work both in the education sector and outside have the motivation to have high competence and are ready to face future competitions.

\section{Keywords: New normal, Hybrid Learning, Study Time Management}

\section{PENDAHULUAN}

Pandemi Corona Viruses Disease-19 (Covid-19) di Indonesia mengakibatkan perubahan pada seluruh aspek tatanan kehidupan. Khususnya pendidikan, proses pembelajaran yang dilaksakanakan secara tatap muka menjadi daring melalui aplikasi yang menunjang pembelajaran daring seperti WhatssApp, Google Clasroom, Edmodo, Zoom dan lain-lain. Satu tahun berlalu pandemi Covid-19 memerlukan tatanan "kehidupan baru" berupa Adaptasi Kebiasaan Baru (AKB). Adaptasi Kebiasaan Baru pada sektor pendidikan tinggi dilaksanakan menurut Surat Edaran Kemendikbud Nomor 0173/E.E2/PM/2021 mengenai Penyelenggaraan Pembelajaran pada Semester Genap Tahun Akademik 2020/2021 bahwa kegiatan perkuliahan dilaksanakan secara daring dan luring (hybrid learning). Adapun panduan penyelenggaraan pembelajaran disusun dalam Keputusan Bersama Tiga Menteri yaitu Kemetrian Pendidikan dan Kebudayaan, Kementrian Agama, Kementrian Kesehatan dan Kementrian dalam Negeri Nomor 04/KB/2020, Nomor 737 Tahun 2020, nomor HK.01.08/Menkes/7093/2020 dan Nomor 420-3987 Tahun 2020.

Sejalan dengan keputusan bersama tiga menteri, Institut Agama Islam Bakti Negara (IBN) Tegal mengeluarkan Surat Edaran Nomor 110/033/SU-IBN/X/2020 mengenai pelaksanaan perkuliahan secara sifting (luring dan daring) secara bergantian setiap minggu. Fakultas Ilmu Tarbiyah dan Keguruan (FITK) program studi Pendidikan Guru Madrasah Ibtidaiyah (PGMI) semester Genap Tahun Akademik 2020/2021 melaksanakan perkuliahan mata kuliah Pembelajaran Tematik Terpadu menggunakan model hybrid learning. Thone dan Kogan dalam Hendrayati dan Pamungkas (2019:181) menyebutkan hybrid learning merupakan model pembelajaran yang mengintegrasikan inovasi dan kemajuan teknologi melalui sistem online learning dengan interaksi dan partisipasi dari model pembelajaran tradisional. Hybrid learning dilaksanakan secara terjadwal oleh pengampu mata kuliah Pembelajaran Tematik Terpadu melalui sebaran materi mata kuliah yang dibagi pada kontrak perkuliahan.

Perkuliahan menggunakan model hybrid learning terlebih dalam masa AKB menuntut mahasiswa program studi PGMI Angkatan 2019 (Semester 4) pandai mengatur waktu belajar, kuliah dan bekerja. Hal tersebut didasari bahwa mahasiswa PGMI sebagian besar bekerja 
untuk memenuhi kebutuhan hidup dan pelaksanaan perkuliahan di siang hari dengan penjadwalan daring dan luring melalui model hybrid learning membutuhkan manajemen waktu yang baik. Manajemen waktu belajar mahasiswa memerlukan keterampilan mengenai cara belajar, proses berfikir hingga memotivasi diri untuk mencapai tujuan pembelajaran. Penggunaan teknologi untuk memaksimalkan perkuliahan daring dipengaruhi oleh persepsi yang diperoleh dari interpretasi panca indra menjadi pemahaman oleh mahasiswa. Kemampuan mahasiswa dalam mengatur waktu belajar menggunakan model hybrid learning dikenal dengan istilah Self Regulated Learning (SRL).

Angket penelitian awal memeroleh hasil bahwa prosentase mahasiswa belajar walaupun tidak ada perkuliahan Pembelajaran Tematik Terpadu dan penyusunan jadwal belajar oleh mahasiswa yaitu 50\% dalam kategori kadang-kadang. Hal tersebut menunjukkan bahwa manajemen waktu belajar mahasiswa PGMI belum tersistem dengan baik walaupun pandemi Covid-19 sudah berlangsung selama satu tahun. Nasrah (2020:209) berpendapat bahwa optimalisasi waktu belajar merupakan hal yang penting karena waktu dan belajar sangat berkaitan. Saat belajar ada beberapa waktu yang menjadi kunci utama memeroleh pembelajaran yang efektif. Manajemen waktu belajar memerlukan kesadaran penuh untuk mengatur waktu yang digunakan untuk belajar. Perkuliahan saat AKB mengaruskan mahasiswa untuk fokus dan memiliki motivasi diri sehingga mereka mau dan mampu menyelesaikan tugas-tugas yang diberikan tepat waktu, (Safuni dan Hidayati, 2020:8).

Model hybrid learning mampu memaksimalkan perkuliahan masa AKB selama Covid19 karena perkuliahan dilaksanakan secara luring dan daring sehingga meminimalisir problema pola komunikasi antara dosen dan mahasiswa serta model perkuliahan selama pandemi Covid-19. Penelitian Hidayat dan Andira (2019:147) menghasilkan bahwa model hybrid learning mampu meningkatkan kognitif dengan perolehan rata-rata nilai 86,17 dan membuat pembelajaran lebih kreatif. Berbeda dengan penelitian Hendrayati dan Pamungkas, (2019:184) menunjukkan bahwa model hybrid learning tidak bisa sepenuhnya dilakukan pada mata kuliah yang bersifat kualitatif. Keterbaharuan dalam penelitian ini yaitu penggunaan model hybrid learning pada matakuliah Pembelajaran Tematik Terpadu. Mata kuliah tersebut merupakan Mata Kuliah Umum (MKU) program studi PGMI dengan beban 2 SKS. Berdasarkan hal tersebut rumusan masalah penelitian ini bagaimanakah manajemen waktu belajar mahasiswa PGMI Semester IV pada mata kuliah Pembelajaran Tematik Terpadu melalui model hybrid learning? 


\section{METODE PENELITIAN}

Penelitian ini menggunakan pendekatan kulitatif deskriptif dengan teknik pengumpulan data dilakukan secara triangulasi (gabungan), analisis bersifat induktif dan hasil penelitian kualitatif menekankan makna dari pada generalisasi, (Sugiyono, 2012:15). Desain penelitian menggunakan penelitian studi kasus. Stake dalam Creswell (2014:20) menyebutkan bahwa studi kasus merupakan strategi penelitian dimana peneliti menyelidiki secara cermat suatu program, peristiwa, aktivitas, proses, atau sekelompok individu. Kasus-kasus dibatasi oleh waktu dan aktivitas. Melalui desain penelitian studi kasus, penelitian ini menganalisis manajemen waktu belajar mata kuliah Pembelajaran Tematik Terpadu mahasiswa PGMI IBN Tegal menghadapi Adaptasi Kebiasaan Baru (AKB) pandemi Covid-19 menggunakan platform e-learning Google Clasroom dan berbantukan YouTube. Fokus penelitian yaitu kemampuan mahasiswa membagi waktu kuliah dan bekerja dengan materi mengenai penyusunan administrasi pembelajaran berupa RPP (Rencana Pelaksanaan Pembelajaran) Kurikulum 2013. Model hybrid learning mata kuliah ini menggunakan jenis web centric course adalah penggunaan internet memadukan antara belajar jarak jauh dan tatap muka dengan prosentase $70 \%$ jarak jauh dan 30\% tatap muka. Partisipan penelitian yaitu 5 mahasiswa PGMI angkatan 2019 yang terdirii dari 1 laki-laki dan 4 perempuan.

Teknik pengumpulan data menggunakan teknik kuesioner melalui Google Formulir yang terintegrasi pada Google Classroom. Wawancara semi terstruktur melalui Google Meeting terjadwal masing-masing partisipan. Teknik keabsahan data menggunakan teknik triangulasi sumber dan teknik. Triangulasi sumber digunakan menguji kredibilitas data dengan mengecek data yang diperoleh dari beberapa sumber, (Sugiyono, 2012:373). Triangulasi sumber penelitian ini yaitu mahasiswa yang kuliah dan bekerja pada sektor pendidikan dan non kependidikan. Sedangkan triangulasi teknik menggunakan data-data yang diperoleh dari angket kuesioner, wawancara dan studi dokumen berupa hasil tugas mahasiswa. Analisis data menggunakan model interaktif Miles and Huberman, bahwa analisis data dilaksanakan terus menerus sampai data sudah jenuh. Analisis interaktif terdiri dari pengumpulan data, reduksi data, penyajian data, dan verifikasi.

\section{PEMBAHASAN}

\section{Komitmen Mahasiswa untuk Kuliah dan Bekerja}

Partisipan penelitian sudah bekerja baik sektor pendidikan maupun di luar sektor tersebut. Pemilihan program studi menjadi prioritas dalam pengaturan manajemen belajar mahasiswa. Manajemen belajar terkait dengan pelaksanaan kuliah dan segala kegiatan 
akademik di dalamnya. Perkuliahan program studi PGMI IBN Tegal diselenggarakan siang hari menjadi daya tarik karena pagi sampai siang partisipan dapat bekerja. Pekerjaan partisipan penelitian mendukung pemahaman terhadap materi dan mampu meningkatkan kompetensi sebagai mahasiswa PGMI IBN Tegal. Partisipan merupakan mahasiswa yang sudah bekerja dengan pengalaman kurang dari lima tahun. Pendapatan yang diperoleh untuk membiayai kuliah dan dari kuliah mereka menambah wawasan keilmuan yang meningkatkan profesionalisme kerja. Partisipan penelitian tidak terbebani bekerja sambil kuliah.

Hal tersebut dibuktikan dengan prosentase manajemen waktu partisipan untuk bekerja dan kuliah sangat baik sebesar $60 \%$ berdasarkan hasil kuesioner. Hasil wawancara menunjukan ada hubungan antara partisipan penelitian yang bekerja sembari menempuh pendidikan melalui bangku perguruan tinggi. Kemandirian secara finansial dan motivasi untuk meningkatkan kompetensi sesuai profesi peneliti peroleh dalam penelitian ini. Partisipan yang bekerja dalam maupun luar sektor pendidikan memitiki motivasi untuk memeroleh kehidupan yang lebih baik apabila mereka menempuh pendidikan tinggi. Gambar 1 dipaparkan lebih lanjut mengenai hubungan bekerja dengan kuliah mahasiswa PGMI Semester IV (Angkatan 2019).

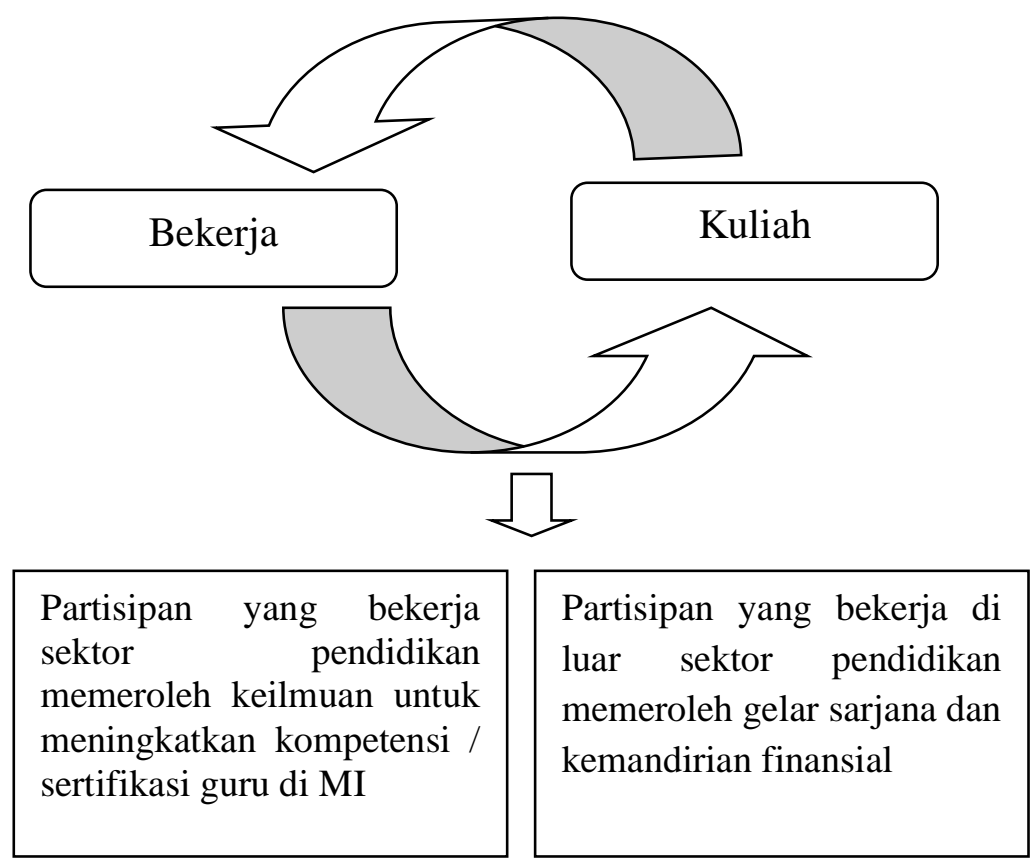

Gambar 1. Hubungan Bekerja dengan Kuliah Mahasiswa PGMI Angkatan 2019

Berdasarkan Gambar 1, partisipan yang bekerja baik dalam atau luar sektor pendidikan memiliki tujuan yang dicapai dengan menempuh pendidikan tinggi. Hal tersebut berlawanan belakang dengan hasil penelitian Fajhriani (2020:10) manajemen waktu belajar selama masa pandemi Covid-19 kurang baik, karena mahasiwa ada yang bekerja, waktu belajar yang tidak 
maksimal, mencari sinyal internet yang cukup jauh, membantu orang tua dan melakukan kegiatan lainnya. Selain strategi pemilihan prodi dengan jadwal kuliah siang hari, partisipan memiliki kemandirian yang diperlukan dalam perkuliahan walaupun bekerja tanggung jawab untuk belajar dan mampu mengatasi problema perkuliahan yang dihadapi saat pandemi. Hal tersebut sesuai dengan penelitian Putra dan Armanto (2020:177) bahwa 84,2\% guru telah memfasilitasi tumbuhanya nilai mandiri pada peserta didik yang tertulis dalam Rencana Pelaksanaan Pembelajaran (RPP) jarak jauh, sedangkan sisanya sebanyak 15,8\% guru belum memfasilitasi pembentukan sikap mandiri tersebut. Paparan tersebut disimpulkan bahwa komitmen partisipan antara bekerja dan kuliah berupa kemandirian dan pengaturan waktu. Partisipan yang bekerja baik dalam maupun luar sektor pendidikan memiliki capaian masingmasing yang mendukung kompetensi masa depan.

\section{Inovasi dan Desain Perkuliahan secara Lengkap}

Inovasi dan desain perkuliahan diawali dengan adanya kontrak perkuliahan mata kuliah Pembelajaran Tematik Terpadu. Kontrak perkuliahan dibahas pula mengenai sebaran materi yang diajarkan dalam waktu satu semester. Sebaran materi merupakan turunan dari RPS namun, lebih lengkap dengan teknis perkuliahan selama satu semester. Sebaran materi perkuliahan diberikan awal pertemuan oleh dosen melalui kontrak perkuliahan dan pemberian soft file melalui Google Classroom. Prosentase kepemilikan sebaran materi perkuliahan sebesar $60 \%$ baik, artinya partisipan memiliki dan membaca isi dari file tersebut. Model hybrid learning jenis web centric course adalah penggunaan internet yang memadukan antara belajar jarak jauh dan tatap muka (konvensional). Sebagian materi disampaikan melalui internet,dan sebagian lagi melalui tatap muka, sedangkan fungsinya saling melengkapi (Prayitno, 2015:9). Berikut Gambar 2 tampilan Google Classroom mata kuliah Pembelajaran Tematik Terpadu.

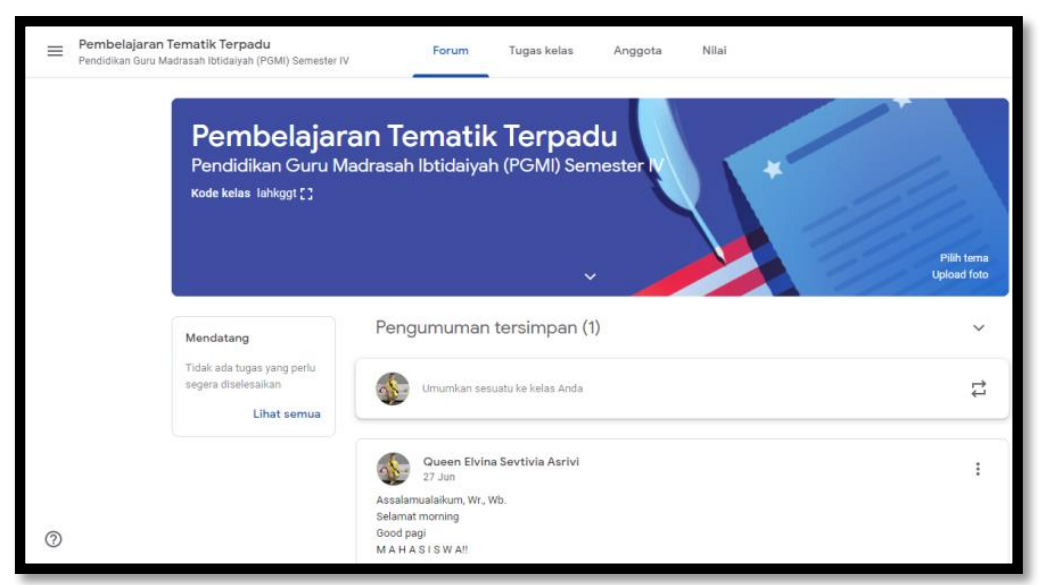

Gambar 2. Tampilan Google Classroom Mata Kuliah Pembelajaran Tematik Terpadu 
Perkuliahan Pembelajaran Tematik Terpadu dilaksanakan dengan prosentase $70 \%$ daring dan 30\% luring menggunakan Google Clasroom berbantukan kanal YouTube menjadi sarana kuliah yang mencakup materi teori mengenai penyusunan administrasi mengajar berupa RPP sedangkan perkuliahan luring menekankan praktek mengenai keterampilan mengajar diantaranya keterampilan membuka menutup pembelajaran, keterampilan memberikan umpan balik pembelajaran, keterampilan menulis, bernyanyi dan keterampilan menguasai ruang kelas. Berikut dokumentasi perkuliahan luring mengenai materi keterampilan mengajar melalui Gambar 3.

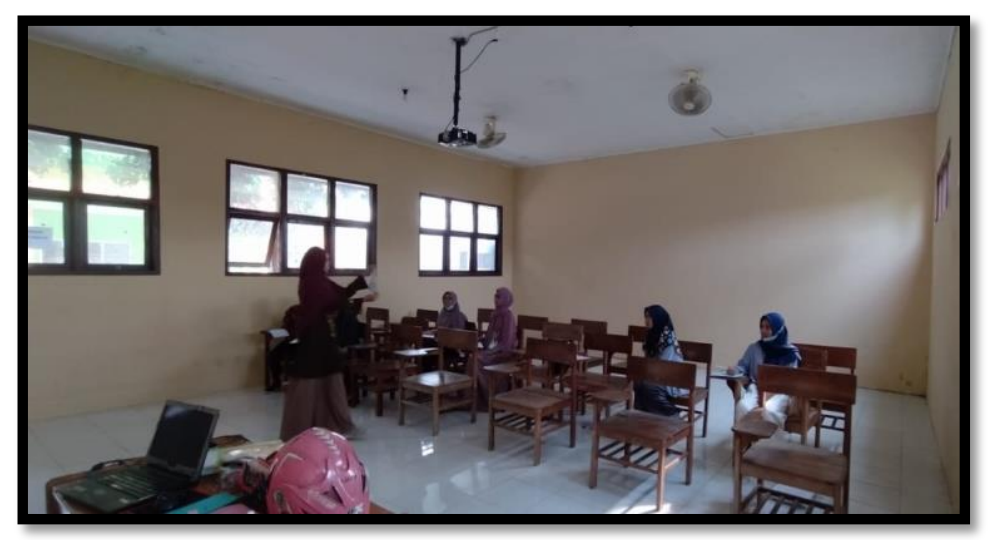

\section{Gambar 3. Perkuliahan Luring Materi Keterampilan Mengajar}

Penelitian Purmadi, Hadi dan Najwa (2018:140) menunjukkan bahwa model hybrid learning sangat penting untuk diimplementasikan di kelas supaya membuka ruang dan akses yang lebih dari sebelumnya. Pembelajaran dengan bantuan teknologi dan sumber belajar yang baik menunjang partisipan dalam mencapai tujuan mata kuliah ini. Hal tersebut berlawanan dengan hasil penelitian Hendrayati dan Pamungkas (2019:184) bahwa hybrid learning tidak bisa sepenuhnya dilakukan pada mata kuliah yang bersifat kuantitatif. Pada mata kuliah yang bersifat kuantitatif benar-benar diperlukan kehadiran dosen secara fisik di dalam kelas. Berdasarkan paparan tersebut, penggunaan model hybrid learning tepat dilaksanakan pada mata kuliah Pembelajaran Tematik Terpadu sesuai dengan capaian mata kuliah ini yaitu mahasiswa mampu menjelaskan dan mendemonstrasikan pembelajaran tematik terpadu yang baik dan benar (K.K.5). Mahasiswa mampu menyusun administrasi ajar melalui penulisan RPP berikut praktik mengajar. 
Kontrak perkuliahan yang dilaksanakan awal perkuliahan sampai dengan pemilihan media pembelajaran menjadi kesepakatan satu semester dibahas bersama antara dosen dan mahasiswa. Hal tersebut sejalan dengan hasil penelitian Herlina (2020:106) bahwa manajemen belajar daring di perguruan tinggi masa pandemi diantaranya adalah inovasi dan desain perkuliahan lengkap serta platform/aplikasi yang sesuai dengan materi perkuliahan. Inovasi dan desain perkuliahan sebagai bentuk pelayanan bagi mahasiswa sehingga aktivitas perkuliahan tetap berlangsung dengan optimal. Penggunaan aplikasi yang menunjang perkuliahan selama pandemi menjembatani aktivitas belajar mahasiswa selama pandemi. Kaitannya dengan penelitian ini penggunaan Google Clasroom berbantukan kanal YouTube menyiapkan partisipan mampu melaksanakan pembelajaran menyeluruh sesuai dengan kompetensi guru madrasah sebagai guru kelas yang harus serba bisa di masa yang akan datang. Kedudukan guru kelas yang mengampu semua mata pelajaran dikemas secara utuh melalui materi yang disampaikan sehingga partisipan mampu meraih capaian pada mata kuliah ini.

\section{Pelaksanaan Adaptasi Kebiasaan Baru (AKB) Mata Kuliah Pembelajaran Tematik}

\section{Terpadu selama Pandemi Covid-19}

Perkuliahan masa Adaptasi Kebiasaan Baru (AKB) Fakultas Ilmu Tarbiyah dan Keguruan (FITK) IBN Tegal merujuk Surat Edaran IBN Tegal Nomor 110/033/SUIBN/X/2020 mengenai pelaksanaan perkuliahan secara sifting (luring dan daring) bergantian setiap minggu. Matakuliah Pembelajaran Tematik Terpadu menggunakan pembelajaran hybrid learning dengan pembagian $70 \%$ daring dan 30\% luring dengan dasar antisipasi perkembangan kasus Covid-19 di Kabupaten Tegal sewaktu-waktu. Perkuliahan luring dilaksanakan sesuai jadwal dengan menerapkan prokes 5M yang dilakukan oleh mahasiswa dan dosen. Penggunaan masker, cuci tangan/menggunakan hand sanitizer dan mengatur jarak tempat duduk. Perkuliahan Pembelajaran Tematik Terpadu sudah sesuai dengan edaran kampus dan kebijakan prokes pemerintah kabupaten Tegal.

Hal menarik penelitian ini yaitu mata kuliah Pembelajaran Tematik Terpadu satusatunya yang menggunakan Google Classroom ketika jadwal kuliah daring sebagai platform edukasi ditambah penggunaan kanal YouTube guna penyampaian materi melalui video oleh dosen dan diunggah pada kanal tersebut.Perkuliahan menggunakan Google Classroom dan media YouTube memudahkan partisipan dalam mengikuti perkuliahan daring. Sebaran materi dan perangkat pembelajaran seperti YouTube yang sudah digunakan sehari-hari memudahkan pemahaman materi mata kuliah ini. Hal tersebut didukung hasil kuesioner mengenai 
penggunaan YouTube sebagai media penyampaian materi dalam perkuliahan daring katergori sangat baik dengan prosentase $80 \%$. Perkuliahan menggunakan Google Classroom dan media YouTube selama AKB mata kuliah Pembelajaran Terpadu menggunakan model hybrid learning berjalan dengan baik sesuai prokes. Sejalan dengan hasil penelitian Hasibuan (2020:5) bahwa sebanyak 20\% mahasiswa memanfaatkan Google Classroom sebagai media pembelajaran, dengan berbagai fitur yang tentunya lebih memudahkan dosen dan mahasiswa untuk membagikan tugas serta adanya transparansi nilai. Penggunaan Google Classroom menjalin komunikasi yang baik antara dosen dengan mahasiswa. Penggunaan selain untuk membagi presensi kehadiran dan membagi materi, secara keseluruhan tidak ada dosen yang tidak masuk perkuliahan, (Herlina, 2020:106).

Dapat disimpulkan bahwa pelaksanaan perkuliahan selama AKB mata kuliah Pembelajaran Tematik Terpadu berlangsung dengan sangat baik. Hal tersebut didukung dengan penerapan prokes saat perkuliahan luring dan penggunaan Google Classroom dan media YouTube mendukung tercapaianya tujuan perkuliahan. Partisipan mampu mengikuti dan melaksanakan perkuliahan dengan mudah sembari bekerja.

\section{KESIMPULAN}

Berdasarkan paparan penelitian dapat disimpulkan bahwa manajemen waktu belajar mahasiswa PGMI Angkatan 2019 selama AKB pandemi Covid-19 berjalan dengan baik. Hal tersebut didukung dengan penggunaan model hybrid learning melalui Google Classroom berbantukan YouTube pada perkuliahan daring memfasilitasi mahasiswa untuk mengikuti perkuliahan. Manajemen waktu dan pemilihan program studi menjadi strategi bagi partisipan yang bekerja pada sektor pendidikan sedangkan bagi partisipan yang bekerja di luar sektor tersebut melihat peluang dapat bekerja dan kuliah bersamaan. Strategi partisipan yang bekerja pada sektor pendidikan untuk peningkatan profesionalisme yaitu memeroleh kesempatan mendapatkan tunjangan guru. Perkuliahan luring selama AKB tentu mengutamakan prokes dan dilaksanakan baik antara partisipan dan peneliti. Pembagian materi antara perkuliahan daring dan luring menjadi strategi bagi peneliti supaya efektif dalam pelaksanaanya.

\section{DAFTAR PUSTAKA}

Creswell, Jhon W. (2016). Research Design Pendekatan Kualitatif, Kuantitatif dan Mixed. Yogyakarta: Pustaka Pelajar

Sugiyono. 2014. Memahami Penelitian Kualitatif. Bandung; Alfabeta.

Ahmad Tanfidzi Putra, Armanto, A. K. (2020). Respons Guru dalam Menumbuhkan Nilai Mandiri melalui Pembelajaran IPS selama Masa Adaptasi Kebiasaan Baru Covid-19 di Jawa Timur. Jurnal Pendidikan Ilmu Pengetahuan Sosial Dan Ilmu-Ilmu Sosial, 2(2), 
$169-184$.

Fajhriani. N, D. (2020). Manajemen Waktu Belajar di Perguruan Tinggi pada Masa Pandemi Covid-19. JIEMAN: Journal of Islamic Educational Management, 1(3), 298-309. https://doi.org/10.35719/jieman.v1i3.27

Hasibuan, M. (2020). Persepsi Mahasiswa terhadap Model Pembelajaran Daring di Masa Pandemi Covid-19 pada Mata Kuliah Ilmu Pendidikan Islam (Studi Kasus Sekolah Tinggi Agama Islam Jam'iyah Mahmudiyah). Jurnal Ilmiah Al-Hadi, 6(1), 16-25.

Hendrayati, H., Pamungkas, B. (2019). Implementasi Model Hybrid Learning pada Proses Pembelajaran Mata Kuliah Statistika II di Prodi Manajemen FPEB UPI. Jurnal Penelitian Pendidikan, 13(2), 181-184.

Herlina, N. (2020). Manajemen Pembelajaran Daring di Perguruan Tinggi Pada Masa Pandemi Covid-19. Journal Civics \& Social Studies, 4(2), 102-108.

Hidayat, M. Y., \& Andira, A. (2019). Pengaruh Model Pembelajaran Hybrid Learning Berbantuan Media Schoology terhadap Hasil Belajar Peserta Didik Kelas XI MIA MAN Pangkep. Jurnal Pendidikan Fisika, 7(2), 140-148.

Nani Safuni, Husna Hidayati, N. F. (2020). Manajemen Waktu selama Pandemi Covid 19 pada Mahasiswa Keperawatan di Kotamadya Banda Aceh. Idea Nursing Journal, XI(1), 6-11.

Nasrah, M. A. (2020). Analisis Motivasi Belajar dan Hasil Belajar Daring Mahasiswa Pada Masa Pandemik Covid-19. Jurnal Riset Pendidikan Dasar, 03(2), 207-213.

Prayitno, W. (2015). Implementasi Blended Learning dalam Pembelajaran pada Pendidikan Dasar dan Menengah. Jurnal Pendidikan, 6(01), 1-14.

Purmadi, A., Hadi, M. S., \& Najwa, L. (2018). Pengembangan Kelas Daring dengan Penerapan Hybrid Learning Menggunakan Chamilo pada Mata kuliah Pendidikan Kewarganegaraan. Jurnal Edcomtech, 3(2), 135-140. 